\title{
TANTANGAN GEREJA-GEREJA CALVINIS DI INDONESIA
}

\author{
Agustinus M.L. Batlajery
}

\section{Pendahuluan}

Dalam bukunya The Reformed Family Worldwide, A Survey of Reformed Churches, Theological Schools and the International Organizations, Jean-Jacques Bauswein and Lucas Visher mencatat bahwa ada empat puluh delapan gereja di Indonesia yang tergolong Reformed atau Calvinis. ${ }^{1}$ Gereja-gereja itu terbentang dari Sumatera sampai Papua dan dari Kalimantan sampai kepulauan Timor. Sebagian besar gereja-gereja itu telah menjadi anggota Persekutuan Gereja-gereja di Indonesia (PGI) baik sejak awal pembentukan Dewan Gereja-gereja di Indonesia (DGI) maupun sesudahnya. Bahkan pada waktu Dewan Gereja-gereja di Indonesia terbentuk tahun 1950, peranan gereja-gereja Calvinis cukup besar. $^{2}$

Secara historis Protestantisme Calvinis atau Reformed telah hadir di Indonesia lebih dari 400 empat ratus tahun, bertepatan dengan hadirnya orangorang Belanda yang berasal dari Gereja Gereformeerd (= Reformed, Hervormd).

\footnotetext{
${ }^{1}$ Jean Jacques Bauswein and Lucas Vischer, The Reformed Family Worldwide A Survey of Reformed Churches, Theological Schools, and International Organizations, Grand Rapids: Eerdmans Publishing Company, 1988, 231-241.

${ }^{2}$ Chr. Hartono, Gerakan Ekumenis di Indonesia, Yogyakarta: Pusat Penelitian dan Inovasi Pendidikan Duta Wacana, 1984, 77.
} 
Dengan demikian dapat dikatakan bahwa aliran protestan yang paling tua di Indonesia adalah aliran Calvinis.

Namun sebagaimana telah dibuktikan oleh sejarah, aliran protestan yang bermula dari Protestantisme Lutheran dan Calvinis itu, telah berkembang sedemikian rupa sehingga melahirkan bentuk Protestantisme lainnya. Protestantisme Lutheran dan Calvinis berada bersama dan berinteraksi dengan berbagai corak protestantisme lainnya seperti Metodis, Baptis, Pentakostal, Karismatik dan Evangelical. Mereka berjalan bersama-sama dalam gerakan oikumene. Namun perbedaan-perbedaan doktrinal dan praktek bergereja tertentu masih mengganggu relasi satu sama lain. Sementara itu kekristenan corak baru yang disebut "kekristenan gelombang ketiga" telah menjadi tantangan tersendiri bagi gerejagereja arus utama di berbagai tempat. ${ }^{3}$

Perkembangan sejarah keagamaan di Eropa misalnya telah membuktikan bahwa sekularisasi serta hadirnya kekristenan gelombang ketiga telah memudarkan protestantisme Calvinis di sana. Gereja-gereja Gereformeerd dan Hervormd menurun jumlah anggotanya secara drastis. De Protestantse Kerk in Nederland (PKN) yang merupakan gabungan dari De Nederlandse Hervormde Kerk, De Gereformeerde Kerken in Nederland dan De Evangelisch-Lutherse Kerk sekarang tengah mengalami masalah ini secara serius.

Pertanyaan yang bisa saja muncul adalah apakah kekristenan Calvinis di Indonesia akan dapat terus bertahan di tengah-tengah arus globalisasi dan hadirnya kekristenan gelombang ketiga? Tantangan-tantangan macam apakah yang dihadapi dan perlu mendapatkan perhatian?

Tulisan ini akan mencoba membahas pertanyaan tersebut di atas. Diawali dengan memaparkan bagaimana ajaran Calvin dan Calvinisme masuk ke Indonesia, dilanjutkan dengan mendeteksi warisan Calvinis macam apa yang masih tersisa dan terpelihara pada gereja-gereja di Indonesia, tulisan ini akan diakhiri dengan beberapa tantangan yang dihadapi.

\section{Masuknya ajaran Calvin dan Calvinisme ke Hindia Belanda}

Sejarah masuknya ajaran Calvin dan Calvinisme ke Indonesia, yang pada waktu itu disebut Hindia Belanda (Dutch East Indie), dalam bagian ini akan

\footnotetext{
${ }^{3}$ Lihat Yahya Wijaya, "Kekristenan 'Gelombang Ketiga,'” (Kata Pengantar) dalam Rijnardus A.van Kooij \& Yam'ah Tsalatsa A, Bermain Dengan Api, Relasi Gereja-gereja Mainstream dan Kalangan Karismatik Pentakosta, Jakarta: BPK Gunung Mulia, 2007, xi-xvii.
} 
diuraikan secara singkat saja. Ada tiga pihak yang membawa corak dan warna ajaran Calvin dan Calvinisme ke Indonesia. Ketiga pihak itu adalah VOC (Veerenigde Oost-Indische Compagnie), perkumpulan badan zending yang dibentuk oleh orang-orang Kristen antar gereja, dan badan-badan zending bentukan gereja Calvinis tertentu.

\section{Ajaran Calvin Masuk ke Hindia Belanda Melalui VOC}

Kekristenan Calvinis diperkenalkan pertama kali oleh orang-orang Belanda bertepatan dengan tibanya VOC di Indonesia. ${ }^{4}$ VOC dibentuk oleh para pedagang Belanda yang kemudian dilegitimasi pemerintah sebagai sebuah kongsi perdagangan. Tujuan utama VOC adalah perdagangan, bukan keagamaan. Mereka diberi hak untuk memerintah seluruh wilayah yang telah dikuasai oleh Republik Belanda, bukan cuma di Asia melainkan juga dari India Selatan sampai Taiwan. Dapat dikatakan bahwa VOC adalah pemerintah yang dengannya gereja di Indonesia harus berurusan. ${ }^{5}$ Tujuan utamanya adalah memonopoli perdagangan rempah-rempah di Asia dan Eropa.

Bahwa VOC tidak bertujuan keagamaan dapat dilihat dari tindakan pertama setelah tiba di Indonesia. Sebagai lembaga yang diberi kewenangan penuh untuk bertindak atas nama Dewan Umum (Staten Generaal) dari Republik Belanda maka dalam rangka memonopoli perdagangan rempah-rempah yang pada masa itu merupakan komoditi paling laku di dunia, VOC melakukan tiga hal: mengusir orang-orang Portugis, menghalangi masuknya orang Spanyol ke Indonesia Timur melalui jalur Filipina, dan memaksa raja-raja pribumi untuk berdagang dengan VOC saja. ${ }^{6}$

Walaupun tidak bertujuan keagamaan, namun karena VOC adalah "pemerintah Belanda di Indonesia" maka keharusan untuk memperhatikan masalah-masalah keagamaan tidak dapat dihindari. Sesuai pemahaman Calvinis dalam artikel 36 dari Pengakuan Iman Belanda (1561), "pemerintah wajib

\footnotetext{
${ }^{4}$ Sebenarnya sebutan yang tepat adalah Hindia Belanda karena waktu itu yang namanya negara Indonesia belum terbentuk. Namun untuk mempermudah pemahaman pembaca masa kini dipakai saja sebutan Indonesia.

${ }^{5}$ Th. van den End, Harta Dalam Bejana, Jakarta: BPK Gunung Mulia, 1979, 219; bnd. H.Berkhof \& I.H. Enklaar, Sejarah Gereja, Jakarta: BPK Gunung Mulia, 237; F.D. Wellem, Kamus Sejarah Gereja, Jakarta: 1994, 264.

${ }^{6}$ Chr. de Jonge, Apa itu Calvinisme, Jakarta: BPK Gunung Mulia, 1998, 30; Th.van den End, Ragi Carita 1, Jakarta: BPK Gunung Mulia, 1999, 33, 65.
} 
melindungi dan memajukan agama yang benar yaitu agama Gereformeerd."7 Oleh karena itu, VOC tidak boleh mengabaikan urusan-urusan keagamaan, malah sebaliknya harus melibatkan diri bahkan bertanggung jawab atasnya. Selain itu, ada dua alasan lain mengapa VOC harus memperhatikan masalah keagamaan. Pertama, oleh karena para awak kapal VOC yang bekerja di Indonesia adalah anggota gereja Gereformeerd. Mereka memerlukan pemeliharaan rohani. Kedua, orang-orang pribumi Katolik yang beralih menjadi Protestan memerlukan pelayanan rohani dari tuan mereka yang baru yakni Belanda karena tuan mereka yang lama yakni Portugis telah diusir. ${ }^{8}$ Tanggung jawab ini secara konkrit dituangkan dalam "Octrooi" (surat kuasa) yang dikeluarkan oleh Dewan Umum pada tahun 1622. ${ }^{9}$ Berdasarkan surat kuasa itu VOC mengklaim semua urusan agama di tangannya seperti peribadahan, organisasi, supervisi, begitu pula keuangan. Akibatnya adalah VOC mengusir semua misionaris Katolik karena dipandang sebagai mata-mata Portugis dan Spanyol dan menggantikannya dengan tenaga Protestan. Dengan langkah semacam ini maka orang-orang Katolik secara otomatis beralih menjadi Protestan, dalam hal ini Gereformeerd.

VOC tidak mempunyai pola sendiri dalam mengorganisasikan kehidupan keagamaan. VOC mengikuti saja pola dari gereja Gereformeerd di Belanda. Dalam ibadah umum dipakai liturgi yang sama dengan yang digunakan di Belanda, jam-jam kebaktian pun sama. Menyangkut perorganisasian gereja, VOC mengikuti tata gereja menurut sistem presbiterial-sinodal, hasil keputusan Sinode Dordrecht (1618-1619) dengan pengecualian di sana-sini, sehingga VOC sendirilah yang mengangkat dan menempatkan para pendeta. Sementara menyangkut pembinaan jemaat digunakanlah dokumen-dokumen pengakuan yang berlaku di Belanda yakni Pengakuan Iman Belanda (1561), Katekismus Heidelberg (1563) dan Pasal-Pasal Ajaran Dordrecht (1619) yang dikenal sebagai Three Forms of Unity. Maka benar jika dikatakan bahwa gereja Gereformeerd di Indonesia merupakan tiruan dari gereja induk di negeri Belanda. ${ }^{10}$ Benarlah apa

\footnotetext{
${ }^{7}$ Jaroslav Pelikan \& Valerie Hotchkiss (eds.), Creeds and Confessions of Faith in the Christian Tradition, Vol.II, London: 2003, 424; Th. van den End, Enam Belas Dokumen Dasar Calvinisme, Jakarta: BPK Gunung Mulia, 2000, 53.

${ }^{8}$ Lihat Chr. de Jonge, "Calvinisme di Indonesia", dalam W. Davidz (ed), Toma Arus Sibak Ombak Tegar, Ambon: 1995, 21.

${ }^{9}$ De Jonge, Apa itu Calvinisme, 31.

${ }^{10}$ Ibid, 31-32.
} 
yang dikatakan De Jonge bahwa dalam hal keagamaan, corak kekristenan yang mewarnai tempat-tempat di mana VOC bekerja serta ajaran yang diberikan baik kepada para pekerja VOC maupun orang-orang pribumi Indonesia adalah satusatunya agama yang benar dan murni yakni iman Kristen yang dimiliki gereja di Belanda yakni Gereformeerd atau Calvinis. Oleh karena itu, hanya Gereja Gereformeerd sajalah yang diizinkan melayani di Hindia Belanda saat itu. ${ }^{11}$

Dengan demikian, Calvinisme yang dibawa ke Indonesia tidak menjangkau seluruh wilayah. VOC hanya bekerja di daerah-daerah yang dianggap bisa mendatangkan keuntungan dagang baginya. Di daerah-daerah itu mereka mendirikan pusat-pusat pemerintahan dan di situlah pula aktifitas keagamaan berlangsung. Oleh sebab itu, maka Ambon (termasuk Banda dan Lease) dan Batavia merupakan tempat-tempat di mana Calvinisme terpelihara, baik di kalangan jemaat orang-orang Belanda maupun jemaat orang-orang pribumi. Di luar wilayah-wilayah ini perhatian terhadap agama sangat sedikit. Di jemaatjemaat Belanda dan jemaat pribumi pada pusat-pusat pemerintahan VOC tersedia pendeta tetapi di luar itu jarang. Perhatian kepada pekabaran Injil sangat kecil walaupun ada kesadaran akan hal itu. Penginjilan dilakukan hanya bila menguntungkan VOC. ${ }^{12}$ Itulah sebabnya, menurut De Jonge, memang corak kekristenan yang ditanamkan pada masa VOC adalah Calvinis namun tidak berakar kuat serta tidak memberikan warna khusus pada jemaat-jemaat Protestan di luar pusat-pusat pemerintahan di mana jemaat-jemaat Belanda berada. Hanya di Ambon dan di pulau-pulau sekitarnya kekristenan ditanamkan dan berakar dalam kehidupan jemaat-jemaat pribumi karena di sana ada pendeta yang aktif bekerja dan orang-orang pribumi sendiri melayani sebagai anggota konsistori (majelis jemaat). Di sana juga berlangsung katekisasi dan sekolah. ${ }^{13}$

Sebagaimana telah dikemukakan, dalam urusan keagamaan VOC mengikuti pola gereja induk di Belanda. Sejauh mungkin mereka berusaha menerapkan di Indonesia cara berorganisasi, ajaran dan praktek bergereja yang berlaku di sana. Maka pada dasarnya ketiga dokumen pengakuan yang digunakan di Belanda menjadi dasar bagi pengajaran dan pemberitaan gereja di sini. Menurut C.W.Th. Baron van Boetzelaer van Asperen en Dubbeldam, kewajiban untuk memegang

\footnotetext{
${ }^{11}$ De Jonge, Calvinisme di Indonesia, 22.

${ }^{12}$ Van den End, Ragi Carita 1, 33-34.

${ }^{13}$ De Jonge, Apa itu Calvinisme, 33-34.
} 
teguh ketiga dokumen ini sebagai dasar pengajaran dan pemberitaan oleh para pendeta dan guru jemaat diatur dalam Tata Gereja tahun 1624. Ditegaskan bahwa setiap pendeta, penghibur orang sakit dan guru jemaat harus menandatangani ketiga dokumen ini. ${ }^{14}$ Untuk menata organisasi dipakailah Tata Gereja yang ditetapkan oleh Sinode Dordrecht (1618-1619) yang mengikuti sistem presbiterial-sinodal.

Meskipun demikian, tidak semua hal yang diatur dalam tata gereja tersebut dapat diterapkan di Indonesia. Dalam praktek terjadi penyesuaian atau adaptasi di sana-sini. ${ }^{15}$ Penyesuaian atau adaptasi perlu dilakukan karena konteks gereja di Indonesia berbeda dengan konteks gereja induk di Belanda.

Kesimpulan yang dapat ditarik dari uraian di atas adalah bahwa orang-orang Indonesia mengenal ajaran Calvin pertama kali bukan dari atau melalui badanbadan pekabaran Injil melainkan melalui sebuah kongsi perdagangan. Kenyataan ini berdampak pada dua hal. Pertama, ajaran yang diperkenalkan dalam ketiga dokumen pengakuan itu tidak tertanam dan berakar dalam pada orang-orang Kristen pribumi Indonesia. Ini disebabkan oleh fakta bahwa tujuan hadirnya VOC bukanlah untuk menanamkan agama. Kedua, karena gereja dikuasai oleh institusi negara, dalam hal ini VOC, maka gereja lalu menjadi gereja negara. Sebagai akibatnya gereja kehilangan otonomi dalam mengatur diri sendiri paling kurang sampai tahun 1934, tatkala Kerkbestuur di Batavia mulai memberikan hak otonomi kepada jemaat-jemaat melalui gerakan pemandirian, pertama-tama di Minahasa, disusul kemudian dengan Maluku dan Timor. Dengan demikian wajah Calvinisme di Indonesia tidak persis sama dengan Calvinisme Belanda. Ini juga disebabkan oleh konteks Indonesia yang memaksa dilakukannya penyesuaian atau adaptasi. Oleh karena itu, dapat dikatakan bahwa Calvinisme di Indonesia merupakan hasil adaptasi Calvinisme Belanda ke dalam konteks Indonesia. ${ }^{16}$

\footnotetext{
${ }^{14}$ C.W.Th. Baron vand Boetzelaervan Asperen en Dubbeldam, De Protestansche Kerk in NederlandsIndie. Haar onwikkeling van 1620-1639, 's-Gravenhage: 1947, 39. Bnd. J. Mooij, Geschiedenis der Protestansche Kerk in Nederlands-Indie, Weltervreden: 1923, 127.

${ }^{15}$ Rincian tentang adaptasi dimaksud dapat dilihat pada Agustinus M.L. Batlajery, The Unity of the Church According to Calvin and Its Meaning to the Churches in Indonesia, Disertasi pada Free University Amsterdam: 2010, 97-100.

${ }^{16}$ Agustinus M.L. Batlajery \& Th. van den End, Ecclesia Reformata Semper Reformanda, Dua Belas Tulisan Mengenai Calvin dan Calvinisme, Jakarta: BPK Gunung Mulia, 2014, 50-68. Th. van den End memakai istilah "Calvinisme yang telah dizinakkan/dikebiri." Lihat Ibid, 123-138.
} 


\section{Gagasan-Gagasan Reformed/Calvinis Masuk ke Hindia Belanda Melalui Badan-Badan Pekabaran Injil Bukan Berbasis Gereja Tertentu}

Jalan lain yang melaluinya gagasan-gagasan Reformed/Calvinis masuk ke Indonesia adalah melalui badan-badan pekabaran Injil dari Eropa. Badan-badan pekabaran Injil itu tidak dibentuk oleh gereja melainkan atas inisiatif anggota dari beberapa gereja. Mereka mulai bekerja pada akhir abad ke-18. Latar belakang pembentukannya didorong oleh perubahan-perubahan yang terjadi di Eropa sejak abad ke-17. Ada dua arus utama yang muncul di Eropa pada waktu itu yakni pengaruh Pencerahan dan bangkitnya Pietisme. Dari antara kedua arus utama ini, Pietisme yang sangat berpengaruh terhadap gerakan pekabaran Injil ke berbagai penjuru dunia termasuk ke Indonesia. ${ }^{17}$ Ketertarikan orang-orang Kristen kepada gerakan pekabaran Injil pada abad ke-18 sesungguhnya merupakan akibat dari pengaruh Pietisme. Gerakan ini berpusat di Halle (Jerman) dan jemaat Herrnhut. Di Belanda, muncul gerakan pekabaran Injil ketika mereka bertemu dengan para pekabar Injil yang diutus dari Herrnhut. Setelah mengamati perkembangan di Inggris dengan terbentuknya The Baptist Missionary Society (1792) dan The London Missionary Society (1795) yang tujuan utamanya adalah pekabaran Injil, timbullah kerinduan dari orang-orang Kristen Belanda untuk membentuk badan-badan misi semacam itu pula.

Sekelompok orang Kristen Belanda membentuk badan pekabaran Injil yang disebut Nederlandsche Zendeling Genootschap atau NZG di Roterdam pada tahun 1797. Sekelompok orang Kristen di Jerman membentuk Rheinische Missionsgesellschaft atau RMG tahun 1828. Pada waktu yang bersamaan sekumpulan orang Kristen di Indonesia yang tidak begitu puas dengan Gereja Protestan di Indonesia karena tidak memberi perhatian pada aspek pekabaran Injil membentuk Javaansch Bijbelgenootschap (Lembaga Alkitab Jawa) yang di kemudian hari berubah nama menjadi Oost Indisch Bijbelgenootschap (Lembaga Alkitab Hindia Belanda). Kemudian dibentuklah pula perhimpunan pekabaran Injil di Batavia, Surabaya dan di tempat-tempat lain pada sekitar tahun 1815. Di samping perhimpunan-perhimpunan ini, ada orang-orang Kristen perorangan yang melakukan pekabaran Injil atas inisiatif sendiri. ${ }^{18}$

\footnotetext{
${ }^{17}$ Van den End, Ragi Carita 1, 139-142.

${ }^{18}$ Ibid, 151-152.
} 
Orang-orang Kristen perorangan yang mendirikan badan-badan pekabaran Injil ini adalah orang-orang yang sedikit atau banyak dipengaruhi oleh Pietisme. Oleh karena itu ciri-ciri Pietisme dapat kita lihat pada badan-badan ini. Mereka tidak terikat pada satu konfesi, tata gereja dan ajaran gereja tertentu. Mereka diutus tidak berdasarkan gelar akademiknya. Cukup saja bila mereka telah diperlengkapi dengan berbagai keterampilan untuk menjamin kehidupannya. Tujuan mereka adalah pertobatan orang-orang yang belum percaya dalam bentuk memiliki kepercayaan hati kepada Tuhan Yesus Kristus sebagai Juruselamat ilahi, yang bagi kita dan ganti kita, telah menanggung dosa-dosa kita di dalam tubuh-Nya di atas kayu salib, serta cinta kasih yang penuh rasa terima kasih terhadap Allah dan sesama manusia, sesuai dengan perintah-perintah Injil. ${ }^{19}$

Kita akan mencoba membahas secara singkat badan-badan misi ini dengan karakteristik teologinya. Kita mulai dengan NZG. Pada mulanya, NZG mengutus para pekabar Injil ke Afrika Selatan, India dan Indonesia. Namun sejak tahun 1839 sampai sekitar tahun 1900 NZG hanya bekerja di beberapa daerah di Indonesia saja seperti Maluku, Minahasa, Timor, Jawa Timur dan Jawa Tengah, Karo di Sumatera, Sulawesi Tengah dan Bolang Mangondow, kemudian di Sulawesi dan Sawo. ${ }^{20}$ Walaupun kelihatannya semua pekabar Injil NZG tergolong ke dalam gereja Gereformeerd, namun berbagai aliran teologi dan corak kerohanian bergabung di dalamnya. Beberapa di antaranya mengikuti tradisi orthodox abad ke-16 dan ke-17, sebagian menginterpretasikan tradisi ini menurut pola Pietisme abad ke-18, sebagian lagi memilih memegang teguh ajaran Calvin sebagaimana tertuang dalam ketiga dokumen pengakuan yang sudah disebutkan di atas. Sementara beberapa lainnya tetap menjalin hubungan dengan gerakan Pietisme Herrnhut serta gerakan kebangunan rohani di Inggris yang bercorak Pietis. Di samping itu ada juga yang dipengaruhi oleh semangat Pencerahan. ${ }^{21}$ Mereka dapat bekerja sama karena sama-sama menekankan pengalaman iman Kristiani dalam kasih dan kesaksian. Jadi NZG terbuka kepada anggota dari berbagai gereja. Para pekabar Injilnya tidak membawa ajaran, konfesi, tata gereja dan liturgi gereja Gereformeerd secara khusus. Mereka merasa

\footnotetext{
${ }^{19}$ Ibid, 152.

${ }^{20}$ Th. van den End, Ragi Carita 2, Jakarta: BPK Gunung Mulia, 1999, 19.

${ }^{21}$ Ibid, 12, 20.
} 
cukup bila berpegang pada Alkitab, Perjanjian Lama dan Baru serta keduabelas pasal Pengakuan Iman Rasuli. ${ }^{22}$

Memperhatikan struktur NZG maka dapat dikatakan bahwa gagasan atau pandangan Calvinis masuk ke dalam lembaga pekabaran Injil ini melalui orangorang yang berpegang pada tradisi orthodox abad ke-16 dan ke-17 serta melalui mereka yang berpegang pada ketiga dokumen pengakuan yaitu Pengakuan Iman Belanda, Katekismus Heidelberg dan Pasal-pasal Ajaran Dordrecht. Maka pada gereja-gereja yang lahir sebagai buah Pekabaran Injil NZG di daerah-daerah yang disebutkan di atas, kita dapat melihat warisan Calvinis berupa penggunaan Katekismus Heidelberg dan buku nyanyian Mazmur, sekalipun kita menyadari bahwa tidak hanya tradisi Cavinis yang tersimpan di sana.

Sebagai akibat dari perbedaan teologi dan corak kerohanian dalam NZG maka pada sekitar tahun 1850-an NZG pecah. Lahirlah Java Comite (JC) pada tahun 1855, kemudian Nederlandse Zendingsvereniging (NZV) pada 1858. Sebelumnya, pada tahun 1847 telah lahir Doopsgezinde Zendings Vereniging (DZV) di samping NZG. Kemudian Java Comite bersama beberapa organisasi pekabaran Injil lain antaranya Neukirchener Mission membentuk Salatiga Zending (Badan Pekabaran Injil Salatiga). Gereja Kristen di Jawa Tengah Utara (GKJTU) merupakan buah penginjilan badan pekabaran Injil ini.

Menyusul NZV dibentuk pula Utrechtsche Zendingsvereniging (UZV) dan Nederlandse Gereformeerde Zendings Vereniging (NGZV) pada tahun 1859. Ketiga badan pekabaran Injil ini (NZV, UZV dan NGZV) didirikan oleh sebagian orang yang memegang ajaran Calvinis dalam NZG tetapi kemudian keluar dari NZG.

NZV bekerja di Jawa Barat di kalangan orang-orang Sunda dan Cina, kemudian di Sulawesi. NGZV aktif di Jawa Tengah dan Sumba. NGZV bergabung kemudian dengan Zending der Gerefomeerde Kerken in Nederlandsch Indie (ZGKN) pada tahun 1894 dan bekerja di Jawa Tengah. Dalam pekerjaannya NGZV berpegang pada teologi Calvinis abad ke-16 dan ke-17 serta ketiga dokumen pengakuan yang disebutkan di atas.

Pada awal abad ke-20 beberapa orang Kristen dari gereja Hervormd di Belanda membentuk Gereformeerde Zendingbond (GZB: 1901). Mereka menggunakan nama Gereformeerd untuk menunjuk kepada tradisi Calvinis abad ke-16 dan ke-17 yang menjadi acuannya, sekalipun beberapa anggotanya mewarisi

\footnotetext{
${ }^{22}$ Ibid, 20.
} 
corak kerohanian Pietistis. Mereka bekerja di tanah Toraja dan di wilayah kerajaan Luwu Sulawesi Selatan. Oleh karena itu Gereja Toraja dan Gereja Luwu (sekarang GPIL) memperlihatkan warna Calvinis dalam organisasi dan ajarannya.

Dari pembahasan singkat tentang beberapa badan pekabaran Injil serta orientasi teologi yang mereka bawa ke Indonesia kita dapat menarik kesimpulan bahwa tidak satupun dari mereka yang secara khusus menyebarkan ajaran Calvinis dan mengembangkannya. Ajaran Calvinis bercampur dengan yang bercorak Pietis. Leonard Hale mengatakan bahwa badan-badan pekabaran Injil seperti NZG, NZV, UZV, NGZV, GZB dan RMG bekerja dengan dua warna yaitu latar belakang Calvinis dan semangat Pietis. ${ }^{23}$ Latar belakang Calvinis tampak dalam penggunaan ketiga dokumen pengakuan gereja Calvinis Belanda. Begitupula warisan tradisi Calvinis dalam ajaran dan praktek bergereja masih dijumpai di sana-sini. Sebagai contoh, banyak gereja di Indonesia sejak permulaan menggunakan sistem Presbiterial-Sinodal dan Katekismus Heidelberg, bahkan sampai sekarang. Sedangkan semangat Pietistik tampak dalam penekanan pada kesalehan hidup ketimbang ajaran yang bersifat konfesional. Yang penting sebanyak mungkin jiwa dapat diselamatkan ketimbang menjadi anggota gereja tertentu.

\section{Gagasan-gagasan Reformed/Calvinis Masuk ke Hindia Belanda Melalui Badan-Badan Pekabaran Injil Gereja Tertentu}

Di samping badan-badan pekabaran Injil yang telah disebutkan di atas, sejak abad ke-19 sampai pertengahan abad ke-20 beberapa gereja Calvinis (Reformed) yang kecil seperti Christelijk Gereformeerde Kerken (CGK) dan Vrijgemaakt Gereformeerde Kerken mulai bekerja di Indonesia. Salah satu badan pekabaran Injil yang patut disebutkan adalah Zending der Gereformeerde Kerken in Nederland (ZGKN). Badan misi ini dibentuk oleh gereja-gereja yang tergabung dalam Gereformeerde Kerken in Nederland (GKN), didirikan tahun 1886. Gereja ini menganut pandangan teologi bahwa pekabaran Injil harus menjadi tugas gereja setempat sebagai lembaga, bukan organisasi yang didirikan oleh orang Kristen perorangan. Bila hasil pekabaran Injil mereka membawa pertobatan maka langsung dibentuk jemaat dengan perangkat organisasi yang levelnya sama

\footnotetext{
${ }^{23}$ Leonard Hale, Jujur Terhadap Pietisme, Jakarta: BPK Gunung Mulia, 1996, 67.
} 
dengan yang ada di Belanda. Sejak tahun 1896,,24 ZGKN bekerja di Banyumas, Kedu, Yogyakarta, Surakarta dan beberapa tempat di Jawa Tengah. ${ }^{25}$ Dalam melayani jemaat-jemaatnya mereka menggunakan buku Mazmur dan Katekismus Heidelberg yang sudah diterjemahkan ke dalam bahasa Jawa yang digunakan sebagai panduan dalam menjelaskan Alkitab sebagai landasan pemberitaan gereja. Rumusan-rumusan yang digunakan dalam sakramen sama dengan yang dipakai di Belanda. ${ }^{26}$ Maka ciri-ciri Calvinis tampak pada gereja-gereja yang lahir sebagai buah penginjilannya. Hal itu dapat dilihat dalam cara mengorganisasikan gereja. Kedudukan jemaat yang satu tidak lebih tinggi dari yang lainnya. Ini mencirikan penggunaan tata gereja yang presbiterial-sinodal.

Semua organisasi misi yang disebutkan di atas berasal dari Gereja Calvinis Belanda (Dutch Reformed Church). Namun ada pula badan pekabaran Injil yang tidak berhubungan dengan gereja ini yakni Doopsgezinde Zendings Vereniging (DZV) yang dibentuk pada tahun 1847 oleh Gereja Mennonite Belanda. Ciri khasnya adalah penolakan terhadap baptisan anak, sumpah dan wajib militer. Faham eklesiologinya adalah kongregasional. ${ }^{27}$ Badan pekabaran Injil ini mulai bekerja tahun 1851 di Jawa Tengah Utara dan kemudian di Sumatera Utara (Angkola-Mandailing). Salah satu gereja yang lahir sebagai buah pekabaran Injil DZV adalah Gereja Injili di Tanah Jawa (GITJ). Mula-mula organisasi gerejanya bersifat kongregasional namun kemudian mengarah ke bentuk sinodal. Salah seorang pekabar Injilnya, Pieter Jansz, adalah orang pertama yang menerjemahkan Katekismus Heidelberg untuk dipergunakan dalam pengajaran di gereja itu. ${ }^{28}$ Maka, meskipun gereja ini pada dasarnya bukan Calvinis namun ajaran Calvinis sempat masuk melalui penggunaan Katekismus Heidelberg.

Akhirnya kita mencatat pula bahwa pada sekitar 30 tahun terakhir dari sekarang, ajaran Calvinis masuk ke Indonesia melalui Gerakan Reformed Injili Indonesia (GRII). Tujuan dari gerakan ini adalah mengembalikan gereja-gereja kepada landasan penyataan Allah berdasarkan Alkitab sebagaimana dikumandangkan oleh para reformator khususnya Calvin dan para pengikutnya, ke masa

\footnotetext{
${ }^{24}$ Hommo Renders, De Gereformeerde zending in Midden-Java, 1859-1931, Zoetermeer: 2001.

${ }^{25}$ Van den End, Ragi Carita 2, 238-239.

${ }^{26}$ Ibid, 240.

${ }^{27}$ Ibid, 21.

${ }^{28}$ Ibid, 233.
} 
kini. ${ }^{29}$ Gerakan ini muncul pada sekitar tahun 1980-an. Mereka berpegang pada Pengakuan Iman Belanda, Katekismus Heidelberg, Pasal-pasal Ajaran Dordrecht, Pengakuan Iman Westminster dan Katekismus Westminster. ${ }^{30}$

Dengan demikian, sejak akhir abad ke-19 sampai pertengahan abad ke-20 kita menemukan badan-badan pekabaran Injil yang bercorak Reformed/Calvinis, dalam hal ini Reformed/Calvinis Belanda. Hanya sedikit saja yang tidak bercorak Reformed/Calvinis seperti DZV (walaupun ada unsur-unsur Calvinis di dalamnya) dan badan pekabaran Injil yang bercorak Lutheran. Ajaran yang mereka bawa tidak lain dari Calvinis. Namun, karena pekerjaannya terbatas di daerah-daerah tertentu saja maka gereja-gereja yang terbentuk sebagai hasil pekabaran Injilnya tidak ditemukan di seluruh wilayah Indonesia. Ketika gereja-gereja itu berdiri sendiri, warna Calvinis berpengaruh. Oleh karenanya kita dapat menemukan ajaran Calvinis pada gereja-gereja tertentu di Indonesia. ${ }^{31}$

Lebih dari pada itu, pengaruh ajaran Calvinis dapat juga ditemukan pada Gereja Baptis, Metodis dan Pentakosta. ${ }^{32}$ Dalam penelitiannya, Aritonang mengatakan bahwa ajaran gereja Baptis tentang otoritas Alkitab serta tentang gereja dan negara, banyak dipengaruhi oleh ajaran Calvinis. J.G. Melton menunjuk kepada The London Confession (1647), The Philadelphia Confession (1742) dan The New Hampshire Confession (1833) yang digunakan gereja Baptis, sesungguhnya merupakan bentuk modifikasi terhadap The Westminster Confession serta memiliki banyak kemiripan dengan pengakuan-pengakuan Calvinis lainnya. ${ }^{33}$ Di dalam The Twenty Five Articles of Religion dari gereja Metodis, ajaran tentang Trinitas, Kristus, Kecukupan Alkitab, Dosa, Keselamatan, dan Hidup Baru terdapat pengaruh ajaran Calvin. ${ }^{34}$ Pengaruh yang sama terlihat pada ajaran tentang kekudusan hidup pada gereja Pentakosta. ${ }^{35}$

\footnotetext{
${ }^{29}$ S.Tong, Gerakan Reformed Injili, Surabaya: Momentum, 1999, 8.

${ }^{30}$ J. Susabda, Pengantar Ke Dalam Teologi Reformed, Surabaya: Momentum, 1994, 5.

${ }^{31}$ Gereja-gereja di Indonesia yang dapat dikategorikan Calvinis dapat dilihat pada buku JeanJaques Bauswein \& Lucas Vischer (eds), The Reformed Family Worldwide yang telah dikutip di muka.

${ }^{32}$ Lihat Jan S. Aritonang, Berbagai Aliran Di Dalam Dan Di Sekitar Gereja, Jakarta: BPK Gunung Mulia, 1995, 139, 161, 169.

${ }^{33}$ J.G. Melton, Encyclopedia of American Religions, Detroit: 1993, 97.

${ }^{34}$ Aritonang, Berbagai Aliran Di Dalam Dan Di Sekitar Gereja, 161.

${ }^{35}$ Ibid, 169.
} 


\section{Warisan Calvinis yang Ditinggalkan}

H. Hendry Meeter menulis:

The significance of John Calvin for the modern era is vividly described by the prominent author in a recent book in these words: 'The sixteenth was a great century. It was the century of Raphael and Michaelangelo, of Spencer and Shakespeare, of Erasmus and Rebelais, of Copernicus and Galileo, of Luther and Calvin. Of all these figures that gave greatness to this century, none left a more lasting heritage than Calvin ${ }^{36}$

Pandangan Henry Meeter ini menunjukkan bahwa Calvinlah yang paling banyak meninggalkan warisan pemikiran teologi baik bagi keagamaan maupun kemasyarakatan. Hal ini dapat dipahami karena ia tidak hanya menulis Institutio yang terkenal itu melainkan tafsiran Alkitab, khotbah, surat-surat, dan traktattraktat, baik menyangkut iman reformasi maupun masalah-masalah kemasyarakatan.

Pada tahun 1992, Douglas F. Kelly, profesor Teologi Sistematika di Reformed Theological Seminary Jackson, Mississipi Amerika Serikat, menulis sebuah buku berjudul "The Emergence of Liberty in the Modern World". Buku itu membahas pengaruh Calvin dan gereja-gereja Calvinis terhadap lima pemerintahan di lima negara yakni Jenewa, Perancis, Scotlandia, Inggris dan di koloni-koloni Amerika antara abad ke-16 sampai abad ke-18. Ternyata kekristenan Calvinis yang hadir di kelima negara tersebut dalam rentang waktu empat abad telah turut mewarnai pola pemerintahan, konstitusi serta pengembangan demokrasi di sana. ${ }^{37}$

Dalam rangka perayaan 500 tahun Yohanes Calvin pada tahun 2009, David W. Hall, seorang pendeta senior Midway Presbyterian Church di Powder Springs, Georgia Amerika Serikat, menulis sebuah buku berjudul "Legacy of John Calvin: His Influence on the Modern World". ${ }^{38}$ Dalam buku itu ia menegaskan bahwa ada sepuluh segi dari kultur modern yang menjadi berbeda karena pengaruh Yohanes Calvin. Kesepuluh segi itu adalah:

\footnotetext{
${ }^{36}$ H. Henry Meeter, Calvinism An Interpretation of Its Basic Ideas, Grand Rapids: Zondervan Publishing House, 1990, 27

${ }^{37}$ Douglas F. Kelly, Munculnya Kemerdekaan di Dunia Modern (terj.), Jakarta: BPK Gunung Mulia, 2000.

${ }^{38}$ David W.Hall, Legacy of John Calvin: His Influence on the Modern World, Phillipsburg, New Jersey: P\&R Publishing Company, 2008. Buku ini telah diterjemahkan dan diterbitkan oleh Penerbit Momentum dengan Judul: Warisan John Calvin: Pengaruhnya di Dunia Modern, 2009.
} 
1. Pendidikan: akademi

2. Kepedulian terhadap orang miskin: the bourse

3. Etika dan interpretasi hukum moral: sepuluh perintah

4. Kemerdekaan gereja: dewan pendeta

5. Pemerintahan melalui dewan: senat

6. Politik-politik yang terdesentralisasi: republik

7. Kesetaraan di antara semua profesi: doktrin panggilan (vokasi)

8. Ekonomi dan keuntungan: tangan yang tidak kelihatan

9. Musik dalam bahasa sehari-hari: buku nyanyian mazmur

10. Kekuatan dari gagasan-gagasan yang diterbitkan: percetakan-percetakan jenewa.

Inilah warisan yang ditinggalkan Calvin akibat pengaruhnya yang besar terhadap tatanan masyarakat dunia. Orang-orang Calvinis, bahkan yang bukan Calvinis di berbagai negara mengakui kebenaran konstatasi David Hall ini.

\section{Warisan Calvinis di Indonesia}

Pertanyaan kita ialah warisan Calvinis macam apa yang masih dapat dilihat pada gereja-gereja di Indonesia sampai sekarang? Beberapa kenyataan yang akan dipaparkan berikut ini merupakan hasil observasi yang bersifat kasar saja:

1. Dalam Pengakuan Imannya Huria Kristen Batak Protestan (HKBP) mengakui ajaran Calvinis tentang gereja yang benar yang dicirikan oleh tiga tanda sebagaimana diajarkan Bucer dan Calvin. Hal ini menarik karena HKBP bukanlah gereja yang"murni" Calvinis melainkan gabungan antara Lutheran dan Calvinis yang disebut Uniert. Tentang tanda-tanda dari gereja yang benar dikatakan: "Kami percaya dan mengaku bahwa gereja menjadi gereja yang benar bila: 1) Firman Allah diberitakan secara murni; 2) Sakramen dilayankan dengan benar sesuai firman Tuhan Yesus Kristus; 3) Disiplin ditegakkan untuk menghindari dosa. ${ }^{39}$ Pengakuan yang sama terdapat pula dalam Pengakuan Iman Gereja Kristen Protestan Indonesia (GKPI), sebuah gereja di Sumatera Utara. Mereka menegaskan dua hal pertama yang menandai gereja yang benar. ${ }^{40}$ Juga pada Gereja Methodis Indonesia. Dalam Dua

\footnotetext{
${ }^{39}$ Dikutip dari Lazarus Purwanto, Indonesian Church Order Under Scrutiny, Kampen: Drukkerij Van den Berg, 1997, 81-82.

${ }^{40}$ GKPI, Pokok-Pokok Pengakuan Iman Gereja Kristen Protestan Indonesia, Pematang Siantar:
} 
Puluh Lima Pokok-Pokok Kepercayaan Methodis, artikel ke-13 dikatakan: "Gereja Kristus yang kelihatan merupakan persekutuan orang percaya di mana Firman Allah diberitakan dan sakramen dilayankan dengan benar menurut ketetapan Kristus." ${ }^{41}$

2. Jika kita memeriksa pemahaman tentang gereja dalam Pemahaman Bersama Iman Kristen (PBIK) kita mencatat bahwa dimensi kekatolikan dan keuniversalan gereja ditegaskan. Gereja tidak terbatas cakupannya. Ia melampaui batas-batas suku, bangsa, bahasa, dan status sosial. Maka Gereja adalah katolik. Sifat kekatolikan dari gereja Yesus Kristus ini dapat ditemukan dalam Pengakuan Iman Belanda pasal 27, dan Pengakuan Iman Westminster pasal 25. ${ }^{42}$ Selanjutnya, pasal 4 ayat 13 dari Pemahaman Bersama Iman Kristen yang berbicara tentang gereja dan negara sangat sejalan dengan ajaran Calvin. Kepada pemerintah sebagai institusi yang ditetapkan oleh Allah dipercayakan tugas melindungi semua orang serta mencegah kejahatan. Orang Kristen diwajibkan berdoa bagi pemerintah dan membantu pemerintah. Namun gereja harus menentang pemerintah bila pemerintah salah menggunakan kewenangan yang diberikan kepadanya. ${ }^{43}$

3. Beberapa gereja menyatakan diri secara jelas sebagai gereja Calvinis dalam pengakuan imannya. Dalam pendahuluan Tata Gerejanya, gereja Toraja menyatakan bahwa pengakuan imannya berhubungan erat dengan Tiga Pengakuan Oikumenis serta Pengakuan Iman gereja-gereja Reformed. Mereka menunjuk kepada ketiga dokumen pengakuan Gereja Belanda, Pengakuan Iman Jenewa dan Pengakuan Iman Westminster. ${ }^{44}$ Dalam hal pengajaran di gereja, buku Katekismus Heidelberg masih dipergunakan beberapa gereja. ${ }^{45}$ Gereja-gereja lain seperti Gereja Toraja, GKJTU, GKT,

1993, 18.

${ }^{41}$ Dikutip dari Lazarus Purwanto, Indonesian Church Orders Under Scrutiny, 100; Cf. Lukas Vischer (ed.), Reformed Witness Today A Collection of Confessions and Statements of Faith Issued by Reformed Churches, Bern: 1982.

42 Th.van den End, Enam Belas Dokumen Dasar Calvinisme, Jakarta: BPK Gunung Mulia, 2000, 43 \& 130.; bnd. I.John Hesselink, On Being Reformed, Grand Rapids: Eerdmans Printing Company, 1988, 87.

${ }^{43}$ PGI, Dokumen Keesaan Gereja, Jakarta: BPK Gunung Mulia, 81.

${ }^{44}$ Vischer, Reformed Witness Today, 48.

${ }^{45}$ GKI Jawa Tengah misalnya menegaskan penggunaan Katekismus Heidelberg dalam Tata Gerejanya. Dalam Pasal 4 dikatakan bahwa sebagai gereja Calvinis, GKI Jateng menerima ajaran reformatoris termasuk Katekismus Heidelberg. Sebelum memiliki buku Katekisasi sendiri GKI 
GBKP, GPIL, GGRI Kalbar, GBST Sumba masih menggunakannya pula. Malah mereka mengembangkannya dengan menyusun apa yang disebut Pelengkap Katekismus Heidelberg (PKH) sebagai upaya mengaktualisasikan iman reformatoris terhadap masalah-masalah kontekstual yang dihadapi sekarang. ${ }^{46}$

4. Pemahaman Calvinis bahwa Firman Allah atau kehendak Allah harus ditegakkan dalam semua lapangan kehidupan masih menjadi pedoman bagi kehadiran orang Kristen dalam masyarakat. firman Tuhan tidak boleh dikungkung dalam tembok-tembok gereja melainkan harus dibawa keluar ke dan di dalam dunia. Termasuk ke dalam dunia politik. ${ }^{47}$ Ngelow mencatat bahwa keterlibatan orang Kristen dalam gerakan kebangkitan nasional merupakan pengaruh dari pemahaman Calvinis ini. Beberapa politisi Kristen menjustifikasi kehadiran mereka dengan merujuk kepada pandangan Calvin dan Abraham Kuyper seperti antara lain Latuihamallo dan Siagian yang melihat politik dan kekristenan sebagai sesuatu kesatuan yang integral dalam arti kekristenan mesti mewarnai politik. Pembentukan Parkindo merupakan implementasi pandangan di atas. ${ }^{48}$

5. Dapat dicatat bahwa Tata Gereja dari banyak gereja di Indonesia menggunakan sistem Presbiterial-Sinodal. Ada yang menyebut sistem ini dalam pendahuluan Tata Gereja, ada yang menempatkannya dalam uraian landasan teologi bagi Tata Gereja itu. ${ }^{49}$ Sistem ini terdiri dari unsur-unsur Sidang Majelis Jemaat, Sidang Klasis, Sidang Sinode Wilayah, atau Sidang Sinode. Lihat pula tata cara pemilihan Majelis Jemaat, pemanggilan pendeta, penatua dan diaken yang dipraktekkan gereja-gereja mirip dengan yang dipraktekkan gereja Calvinis di berbagai tempat.

6. Dalam hal liturgi dan nyanyian gereja yang dipakai gereja-gereja di Indonesia, warisan Calvinis masih dapat dijumpai. Salah satu sumbangan Calvin yang penting bagi liturgi gereja-gereja Calvinis adalah rumusan Votum yang

\footnotetext{
Jateng menggunakan buku Pengajaran Agama Kristen Katekismus Heidelberg yang diterbitkan BPK Gunung Mulia Jakarta.

${ }^{46}$ Lihat LPPPK GKJTU Sabda Mulia, Menjadi Murid Sejati Abad XXI Pelengkap Katekismus Heidelberg, Jakarta: Yayasan Bina Kasih, 2013.

${ }^{47}$ Z.J. Ngelow, Kekristenan dan Nasionalisme, Jakarta: BPK Gunung Mulia, 1994, 89-93; Bnd. S. Sirait, Politik Kristen di Indonesia Suatu Tinjauan Etis, Jakarta: BPK Gunung Mulia, 2000, 210-214.

${ }^{48}$ Ibid, 91-92.

${ }^{49}$ Lihat Lazarus Purwanto, Indonesians Church Order Under Scrutiny, 28, 62.
} 
dikutip dari Mazmur 124:8. Calvin menyebutnya "adjutorium".50 Menurut Abineno, rumusan Votum: "Pertolongan kepada kita ialah di dalam nama Tuhan", adalah sebuah unsur liturgi warisan Calvin bagi gereja-gereja Calvinis di Indonesia, warisan mana mereka terima dari gereja-gereja Calvinis Belanda. ${ }^{51}$ Buku Nyanyian Mazmur masih digunakan oleh beberapa gereja walaupun tidak sesering Kidung Jemaat, Pelengkap Kidung Jemaat atau Nyanyian Kidung Baru. Namun ada gereja, umpamanya Gereja Jemaat Protestan Indonesia (GJPI) di Papua Barat yang didirikan sebagai buah pekabaran Injil gereja Gereformeerde Gemeenten in de Nederlands, hanya menyanyikan Mazmur dalam ibadah.

7. Menyangkut ibadah perjamuan kudus, masih terdapat tradisi yang disebut "perhadliran".52 Perhadliran dilaksanakan seminggu sebelum ibadah perjamuan kudus. Juga apa yang disebut Kamis Putih (Maundy Thursday), ${ }^{53}$ yang diadakan sebelum Jumat Agung untuk mengenang kematian Yesus Kristus. Perhadliran dimaksudkan untuk menguji diri sendiri sebagaimana yang Paulus maksudkan dalam surat 1Kor.11:28. Sedangkan Kamis Putih dimaksudkan sebagai momen refleksi tentang perjamuan malam yang Yesus adakan dengan murid-murid-Nya menyongsong kematian-Nya. Tradisi ini sejalan dengan tata ibadah perjamuan kudus dalam gereja-gereja bertradisi Calvinis.

Beberapa warisan Calvinis yang disebutkan di atas dapat ditambah dengan sederetan aspek lagi bila dilakukan penelitian lebih lanjut. ${ }^{54}$ Dengan keenam pokok ini cukuplah bagi kita untuk memahami bahwa sedikit atau banyak, warisan tradisi gereja Calvinis masih tersimpan pada gereja-gereja di Indonesia.

\section{Tantangan Gereja-gereja Calvinis di Indonesia}

Diskusi tentang relevansi ajaran Calvin dan Calvinisme bagi gereja-gereja di Indonesia muncul dalam sebuah Seminar tentang Calvin dan Calvinisme yang

\footnotetext{
${ }^{50}$ Rasid Rachman, Pengantar Sejarah Liturgi, Tangerang: Bintang Fajar, 1999, 96.

51 J.L.Ch. Abineno, Unsur-Unsur Liturgi Yang Dipakai Gereja-Gereja Di Indonesia, Jakarta: BPK Gunung Mulia, 2000, 3; bnd. Liturgi karangan Calvin dalam buku Enam Belas Dokumen Dasar Calvinisme, 417-418.

${ }^{52}$ Khusus di GPM

${ }^{53}$ Dapat ditemukan di GPIB dan GKI.

${ }^{54}$ Lihat Batlajery, The Unity of the Church According to Calvin and Its Meaning to the Churches in Indonesia, 147-151.
} 
diselenggarakan oleh Indonesian Calvin Society pada bulan Juli tahun 2000. Pertanyaan-pertanyaan yang diajukan antara lain: apakah ajaran Calvin yang dirumuskan pada abad ke-16 masih relevan dengan situasi gereja-gereja di Indonesia abad ke-21 yang modern ini? Apa gunanya penggalian dan pendalaman ajaran Calvin pada masa kini? Bukankah itu hanya akan memicu bangkitnya fanatisme denominasional pada gereja-gereja yang tidak beraliran Calvinis sehingga dapat mengakibatkan perpecahan ${ }^{55}$

Secara umum dapat disimpulkan bahwa perbedaan konteks menjadi faktor utama dari persoalan tentang relevansi pemikiran Calvin dan Calvinisme. Calvin mengembangkan ajarannya dalam konteks Corpus Christianum serta dalam wilayah kontinental Eropa yang berbeda dengan Indonesia yang dapat dikatakan negara-kepulauan. Perbedaan rentang waktu serta masalah-masalah kekristenan yang muncul juga tidak sama. Hal ini memang dapat difahami.

Beberapa pemikiran kritis terhadap Calvin dan Calvinisme berkembang akhir-akhir ini. Ada yang berpendapat bahwa doktrin Calvin tentang predestinasi rangkap adalah keliru jika diuji dengan kesaksian Alkitab. Kesaksian surat Kolose 1:15-20 bertentangan dengan ajaran predestinasi rangkap. Sebab tidak satu hal pun yang ditetapkan oleh Allah tanpa Kristus atau di luar Yesus Kristus. Doktrin ini juga tidak dapat dipertahankan dari perspektif budaya, khususnya budaya suku Atoni di Timor karena tidak ditemukan analoginya dalam ukiran suku Atoni yang dinamakan tiba. Oleh karena itu, dogma predestinasi yang pernah ada dalam sejarah gereja dianggap menyesatkan. ${ }^{56}$

Ada yang berpendapat bahwa tidak penting apakah seseorang atau sebuah gereja menjadi Calvinis (dapat ditambahkan Lutheran, Metodis, Baptis, dst.) atau tidak. Yang penting adalah perbuatannya. Kehidupan dan iman seseorang dinilai bukan dari segi denominasional-konfesional yang ia anut atau dari sudut denominasi mana ia berasal. Penegasan Matius 7:21 dan 25:31-46 adalah pada perbuatan, bukan pada apakah seseorang harus menjadi Calvinis dan sebagainya. Sebuah gereja menjadi gereja bukan karena gereja itu berpegang pada ajaran Calvinis atau menggunakan struktur bergereja yang presbiterial-sinodal. Sebuah gereja menjadi gereja karena gereja itu melakukan sesuatu bagi kemanusiaan. Perbuatan-perbuatan kemanusiaan itulah yang menentukan gereja sebagai

\footnotetext{
${ }^{55}$ Lihat Batlajery \& Van den End, Ecclesia Reformata Semper Reformanda, 1.

${ }^{56}$ Eben Nuban Timo, Pemberita Firman Pencinta Budaya, Jakarta: BPK Gunung Mulia, 2005, 151155. Sejumlah argumentasi dikemukakan dalam buku ini.
} 
gereja. Pembicaraan tentang Calvin dan Calvinisme tidak relevan dengan situasi Indonesia karena seandainya Calvin hidup dalam masyarakat majemuk seperti Indonesia, di mana penganut Islam adalah mayoritas, maka pasti ia akan menulis lain. Ia tidak mungkin menerapkan "Geneva magistrate" di Indonesia. ${ }^{57}$ Inilah kritik terhadap gereja-gereja Calvinis sekaligus tantangan internal yang bersifat doktrinal.

Selanjutnya, dengan hadirnya kekristenan corak baru atau kekristenan gelombang ketiga ${ }^{58}$ (Karismatik dan sejenisnya) maka gereja-gereja mainstream menghadapi tantangan tersendiri (termasuk Calvinis). Walaupun dari segi ketertarikan, gereja-gereja tradisional di Indonesia tidak mengalami kebangkrutan sebagaimana yang terjadi dengan gereja-gereja tradisional di Eropa Barat, karena perkembangan gereja-gereja corak baru terjadi bersamaan dengan gerak laju gereja-gereja tradisional, ${ }^{59}$ namun toh relasi gereja-gereja mainstream dengan gereja-gereja ini mengalami gangguan yang berpotensi destruktif terhadap kehidupan bersama secara oikumenis. Ini merupakan tantangan external.

Persoalan lain adalah mengenai pemahaman tentang hubungan gereja dan politik serta pengimplementasiannya oleh para pemimpin gereja yang nota-bene Calvinis. Dalam paham Calvinis, politik merupakan bidang kesaksian dan pelayanan gereja. Injil harus mewarnai bidang politik. Faham ini dijabarkan melampaui batas sehingga mencakup politik praktis. Para pendeta cenderung menjadi politisi partai tertentu, para pemimpinnya bertindak mendukung partai politik atau kandidat tertentu pula. Gereja bukan lagi lembaga ilahi yang menjaga moralitas, integritas dan memayungi semua pihak. Dimensi transendental gereja yang menentukan hakekatnya dikalahkan oleh dimensi sosial-imanen. Gereja jatuh kepada keberpihakan yang simplisistis dan telah melayani kepentingan pihak tertentu. Bahkan gereja bagaikan sebuah partai politik pada setiap pesta demokrasi.

Tantangan lain yang perlu diperhatikan adalah eklesiologi reformatoris Calvinis dalam kaitan dengan etnisitas. Bagaimana eklesiologi Calvinis berha-

\footnotetext{
${ }^{57}$ John Titaley, GPM dan Warisan Protestantisme: Perspektif Kontekstualisasi, Ambon: 2008, 2-3 (paper tidak dipublikasikan).

${ }^{58}$ Lihat Yahya Wijaya, "Kekristenan 'Gelombang Ketiga,"' (Kata Pengantar) dalam Rijnardus A.van Kooij \& Yam'ah Tsalatsa A, Bermain Dengan Api, xii.

${ }^{59}$ Ibid, xvi
} 
dapan dengan kecenderungan etnisitas yang kuat dalam masyarakat dan gereja sendiri? Gerrit Singgih dalam bukunya Mengantisipasi Masa Depan (2004) mengatakan bahwa etnisitas menjadi salah satu masalah nasional dan lokal bahkan internal gereja pada permulaan abad ke-21. ${ }^{60}$ Dengan demikian, etnisitas telah menambah deretan masalah yang dihadapi bangsa dan gereja pada abad ini.

Pada gereja-gereja Calvinis di Indonesia, persoalan etnisitas biasanya muncul tatkala terjadi pergantian kepemimpinan secara periodik. Wacana kesukuan, orang asli dan pendatang tampil ke permukaan. Padahal eklesiologi reformatoris, juga Calvinis, justeru menabrak sikap dan kecenderungan semacam ini.

Akhirnya kita harus mengakui bahwa gereja-gereja Calvinis di Indonesia, bersama-sama dengan gereja-gereja lainnya sedang dan mungkin akan terus menghadapi persoalan pluralitas di mana dominasi agama tertentu seolah dibenarkan oleh negara. Tidak hanya itu. Tindakan kekerasan atas nama agama terhadap agama lain atau kelompok lain dibiarkan oleh negara. Negara dengan pemerintahan yang kuat tidak lagi dapat diharapkan. Apalagi untuk menjalankan kehendak Allah yaitu melindungi orang baik dan memberantas segala bentuk kejahatan sesuai cita-cita Calvinis?

\section{Kesimpulan}

Dari catatan sejarah di atas jelas terlihat ajaran Calvinis yang dibawa ke Indonesia tidak diperhatikan secara sungguh-sungguh oleh VOC. Lagi pula badanbadan Zending yang bekerja di Indonesia, dengan beberapa pengecualian, tidak membawa secara khusus ajaran Calvinis. Ini menyebabkan ajaran Calvinis tidak tertanam dan berakar dengan baik di daerah-daerah tertentu. Oleh karena itu ke depan rasanya, tingkat intensitas menggali dan mendalami ajaran Calvin dan Calvinisme perlu semakin ditingkatkan pada gereja-gereja Calvinis di Indonesia. Apakah ajaran Calvin dan Calvinisme mulai memudar akibat lajunya perkembangan teologi gereja dan masyarakat? Ataukah justeru menghadapi lajunya arus teologi gereja dan masyarakat, masih dapat ditemukan pegangan yang kokoh dan fundamental dari padanya?

\footnotetext{
${ }^{60}$ Emanuel Gerrit Singgih, Mengantisipasi Masa Depan, Jakarta: BPK Gunung Mulia, 2004, 124157.
} 
Dalam hal ini patut disebutkan upaya yang dilakukan gereja-gereja Calvinis yang tergabung dalam jaringan gereja-gereja reformatoris di Indonesia. Dengan dan bersama GKJTU sebagai inisiator, gereja-gereja ini merumuskan Pelengkap Katekismus Heidelberg (PKH). Katekismus Heidelberg memang dipandang memuat dan membahas hal-hal mendasar dari iman gereja reformatoris Calvinis. Namun isu-isu aktual yang muncul sekarang jauh dari sentuhannya. Oleh karena itu diperlukan Pelengkap Katekismus Heidelberg yang menyentuh masalah dan isu semacam ini. Oleh karena itu dalam PKH, kebudayaan, kemajemukan agama, politik, ekonomi dan Iptek adalah isu-isu aktual yang disoroti dengan bertitik tolak pada iman reformatoris Calvinis. Studi-studi semacam ini patut dihargai dan didorong perkembangannya. Artinya melalui studi-studi semacam ini kita akan dapat memperoleh gambaran, mana ajaran Calvin dan Calvinisme yang masih relevan dan mana sudah yang tidak relevan lagi.

Berdasarkan hasil penelitiannya Van Kooij dan Tsalatsa merekomendasikan beberapa hal dalam rangka meminimalisasi ketegangan antara Gereja Mainstream (GM) dan Kelompok Karismatik Pentakostal (KKP). Salah satu rekomendasi adalah membangun dialog. Pokok-pokok yang dapat menjadi bahan dialog antara lain tentang panggilan gereja, tentang baptisan, serta liturgi dan simbol. ${ }^{61}$ Ini pada satu pihak dapat dikatakan sebagai kesempatan, namun sekaligus tantangan pada pihak lain. Pokok-pokok yang menjadi inti dialog justeru pokok-pokok yang krusial yang tentangnya nyaris tak pernah tercapai kesepahaman. Namun masih ada optimisme bila GM dan KKP dapat membuka diri untuk saling belajar dan mengoreksi diri sendiri. Seberapa jauh GM bisa menerapkan ibadah kreatif yang sudah biasa pada KKP? Sejauh mana KKP dapat mengontrol ekpresi pengalaman karismatik sehingga tidak jatuh ke dalam suatu bentuk pengejaran yang bersifat jalan pintas menuju ilusi dan kepalsuan ${ }^{62}$

Memang kecenderungan mempertahankan identitas diri sehingga membedakannya dengan pihak lain cukup kuat pada GM termasuk Calvinis. Ini merupakan tantangan tersendiri pula. Namun harus disadari bahwa gereja Calvinis sesungguhnya adalah gereja yang mudah beradaptasi dengan konteks. Dengan bertolak pada ajaran Calvin, gereja Calvinis dapat malakukan pengembangan di

\footnotetext{
${ }^{61}$ Van Kooij dan Tsalatsa, Bermain dengan Api, 192-194.

62 Ibid, 194.
} 
sana-sini sesuai dengan konteks sambil menjaga agar tidak kehilangan aspekaspek yang fundamental dari iman Kristen.

Benar bahwa Neo-Calvinisme ala Abraham Kuyper membuka peluang yang amat lebar bagi peran politik warga gereja dalam negara dengan berusaha meraih posisi-posisi tertentu, bahkan bila mungkin, yang sangat menentukan. Namun hal itu tidak boleh menyeret institusi gereja ke dalamnya. Kendati partisipasi politik orang Kristen diperlukan, namun kewibawaan institusi gereja harus selalu dijaga agar tidak terjerumus ke dalam perjuangan kepentingan kelompok tertentu yang terbatas. Kepentingan tiap kelompok politik tidak serta merta dapat diidentikkan dengan kebenaran, keadilan, perdamaian dan kesejahteraan yang kerap menjadi dasar teologis perjuangan dan partisipasi gereja di bidang politik.

Dalam kaitan itu eklesiologi reformatoris Calvinis perlu didalami. Calvin ingin mengembalikan gereja kepada hakekatnya sebagai tubuh Kristus di mana Kristus adalah kepala. Gereja harus tunduk kepada Kristus Sang kepala itu, bukan kepada pemimpinnya yang seolah mengambil alih posisi Kristus sang kepala. Kristus adalah Kristus untuk dan bagi semua. Ia telah merobohkan segala tembok pemisah. Gereja haruslah menjadi gereja. Gereja bukan lembaga kemasyarakatan dalam arti yang penuh. Gereja menampung semua suku, agama, ras, golongan, bangsa dan bahasa. Oleh karena itu, mengembangkan primordialisme berbasis etnik dalam gereja adalah perbuatan menghina gereja selaku Tubuh Kristus. 